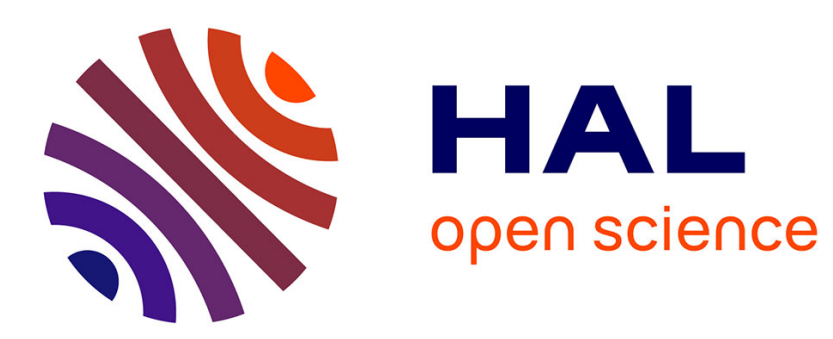

\title{
Dislocation arrangement of Nb-34 at\% Ta alloy single crystals deformed in tension
}

W. Wasserbäch

\section{To cite this version:}

W. Wasserbäch. Dislocation arrangement of Nb-34 at\% Ta alloy single crystals deformed in tension. Revue de Physique Appliquée, 1988, 23 (4), pp.671-671. 10.1051/rphysap:01988002304067100 . jpa00245820

\section{HAL Id: jpa-00245820 https://hal.science/jpa-00245820}

Submitted on 1 Jan 1988

HAL is a multi-disciplinary open access archive for the deposit and dissemination of scientific research documents, whether they are published or not. The documents may come from teaching and research institutions in France or abroad, or from public or private research centers.
L'archive ouverte pluridisciplinaire HAL, est destinée au dépôt et à la diffusion de documents scientifiques de niveau recherche, publiés ou non, émanant des établissements d'enseignement et de recherche français ou étrangers, des laboratoires publics ou privés. 


\section{DISLOCATION ARRANGEMENT OF Nb-34 ato Ta ALIOY SINGLE CRYSTALS DEFORMED IN TENSION}

\section{W. WASSERBÄCH}

MAX-PLANCK-INSTITITT FUR METALLFORSCHUNG, D-7000 STUTTGART 80

High-purity Nb-Ta alloy single crystals oriented for single slip have been deformed in tension at intermediate temperatures. The dislocation behaviour and arrangement have been studied by slip-line observations Laue X-ray back-reflection, X-ray topography and transmission electron microscopy. The slip-line investigations indicate that the maximum resolved shear stress plane MRS is the macroscopic active plane. The workhardening curves resemble that of fcc metals with an extended stage I. However, the experimental findings suggests that a gradual transition occurs from stage I into stage III and that the characteristic features of stage II are missing.

In stage I of the work-hardening curve primary dislocations are predominantly observed, grouped into bundles of edge dipoles and multipoles. Fine and homogeneous slip traces on the surface show that the slip proceeds homogeneously in the whole volume of the crystal. These observations indicate that there are no serious obstacles to the movement of primary dislocations in stage $I$.

At the end of stage I the majority of the dislocations have still accumulated in the multinole bundles. However, in positions where local secondary slip occurred dislocations sheets about parallel to the MRSS plane begin to form. These sheets which are created in pairs consist of primary and secondary dislocations. The formation of the dislocation sheets during the transition stage is accompanied by a dissolution of the primary multipole braids and seems to be completed at the beginning of stage III.

The dislocation arrangement in stage III consists of two different types of structures: Besides the above mentioned dislocation sheets walls of accumulated edge dislocations perpendicular to the primary slip direction are observed. These walls give rise to a characteristic S-shaped bending of the slip plane and end usually inside the crystal. The dislocation sheets which consist of a crossed grid of primary and secondary dislocations give rise to a characteristic lattice rotation. The two sheets of a pair are linked together by secondary slip between them. Outside the sheet pairs indication for secondary slip is rare.

Further deformation into stage III remains the average sheet arrangement almost unchanged, whereas the densities of the primary and secondary dislocations increase with increasing strain. The density of the secondary dislocations increases faster than the density of the primary dislocations. The dependence of the dislocation density of the primary dislocations on strain can be explained by taking into ascount the mutual annihilation of primary dislocation of opposite signs. By contrast. the rate of annihilation of secnndary dislocations is rather small, despite of their high density, because of their low flux. Since only primary dislocations glide over large distances: a high density of primary dislocations is responsible for the macroscopic glide; i. e. a high annihilation rate is expected.

Long-range stresses are present after deformation into stage III. However, in contrast to fcc metals, piled-up groups of primary dislocations are not observed in our $\mathrm{Nb}-\mathrm{Ta}$ alloy specimens. Due to the fact that in bcc metals a low stress level is sufficient for easy cross-slin of screw dislocations piled-un dislocations play a much smaller role in work-hardening than in fcc metals. The formation of dislocation sheets composed of primary and secondary dislocations and the accompanying longrange stresses are mainly responsible for the increase of the work-hardening beyond stage I. The dislocation sheets originate from primary glide dislocations that were immobilized by reactions with secondary dislncations where local secondary slip could occur. In order to reduce the internal stresses at larger distances from the sheets these occur in pairs as sheet dipoles. The dislocation sheets are strong obstacles for secondary slip but they are overcomed by extensive cross-slip of primary screw dislocations. Even though the slip-line morpholngy of stage III is quite different to that of stage I - i.e. highly localized slip in bands is observed in stage III - the macroscopic deformation in stage III takes place on the MRSS glide system by glide of primary dislocations over large distances similarly to stage. I. 